\title{
UM PANORAMA DAS VIOLAÇÕES E DISCRIMINAÇÕES ÀS RELIGIÕES AFRO- BRASILEIRAS COMO EXPRESSÃO DO RACISMO RELIGIOSO $^{1}$
}

\author{
Ariadne Moreira Basílio de Oliveira² \\ DOI: https://doi.org/10.26512/revistacalundu.v2i1.9545
}

\section{Resumo:}

O presente artigo visa evidenciar as formas com que as religiões afro- brasileiras têm sido discriminadas e o embasamento racista dessas discriminações. Para tanto, selecionei alguns casos emblemáticos que expressam um panorama das variadas formas de discriminação e violações a essas religiões, sem, contudo, esgotar a questão. Esse panorama, que foi dividido em tópicos para expressar a variedade de casos, contém relatos, dados jurídicos, sociais, midiáticos, que, mesclados, esboçam um histórico, assim como aponta para os percursos das discriminações.

Palavras chave: Religiões afro-brasileiras; discriminação; violação de direitos; criminalização; racismo religioso.

\section{UN PANORAMA DE LAS VIOLACIONES Y DISCRIMINACIONES A LAS RELIGIONES AFRO- BRASILEÑAS COMO EXPRESIÓN DEL RACISMO RELIGIOSO}

\section{Resumen}

El presente artículo pretende evidenciar las formas en que las religiones afrobrasileñas han sido discriminadas y el fundamento racista de esas discriminaciones. Para tanto, seleccioné algunos casos emblemáticos que expresan un panorama de las variadas formas de discriminación y violaciones a esas religiones, sin, no obstante, agotar la

\footnotetext{
${ }^{1}$ Este artigo é derivado do terceiro capítulo da minha dissertação de mestrado no Programa de PósGradução em Direitos Humanos e Cidadania pela Universidade de Brasília defendida em agosto de 2017. ${ }^{2}$ Mestra em Direitos Humanos e Cidadania pela Universidade de Brasília. Integrante do Calundu - Grupo de Estudos sobre Religiões Afro-Brasileiras. ariadnebasilio@gmail.com
} 
cuestión. Este panorama, que fue dividido en tópicos para expresar la variedad de casos, contiene relatos, datos jurídicos, sociales, mediáticos, que, mezclados, esbozan un histórico, así como también apunta para los itinerarios de las discriminaciones.

Palabras clave: Religiones afrobrasileñas; discriminación; violación de derechos; criminalización; racismo religioso.

\section{Introdução}

A prática de discriminação às religiões afro-brasileiras se inicia antes mesmo da estruturação dessas religiões no Brasil quando as crenças e rituais trazidos da África a partir da vinda forçada de africanos e africanas escravizados são proibidas em suas variadas dimensões. De fato, as religiões, cultos e crenças que respaldaram a construção das religiões afro em terras brasileiras já eram em África discriminadas pelos colonizadores europeus.

A partir da imposição de uma colonização violenta, respaldada pelo mito salvacionista cristão, as diversas práticas, valores, conhecimentos e saberes trazidos de África para o Brasil ou ainda as práticas e conhecimentos dos vários povos indígenas, que se contrapunham as ocidentais, ou que não as auxiliassem na explicação, justificação ou manutenção do domínio do colonizador foram rechaçadas, proibidas, para dar lugar a imposição da lógica ocidental de compreensão e funcionamento do mundo (DUSSEL, 2014; QUIJANO; 1991).

A partir de uma série de cenários que contemplam a historicidade de leis, medidas sociais, atuação midiática e policial, entre outros, forja-se este artigo que tem por intuito evidenciar como as perseguições, discriminações e violações às religiões afro-brasileiras ocorreram e ocorrem no Brasil e como o racismo fundamenta a da construção desse complexo panorama.

Inicialmente trago o cenário histórico das criminalizações, seguido das imbricações políticas e midiáticas no envolvimento com intervenções policiais; posteriormente há uma explanação sobre as discriminações no contexto escolar que se encontra associada à obrigatoriedade do ensino religioso nas escolas, assim como a adoção das religiões cristãs como padrão universal, o que serve de conexão para o próximo cenário que traz as discriminações realizadas por integrantes de religiões neopentecostais. Por fim, trago uma reflexão a partir dos ataques deferidos 
aos espaços dos terreiros, assim como aos membros das comunidades de terreiro, em especial nos últimos anos.

\section{A liberdade religiosa}

Na atual Constituição da República Federativa do Brasil, promulgada aos cinco de outubro de 1988 (CF/88), a liberdade de crença e de expressão, assim como a não interferência do Estado na esfera religiosa, estão asseguradas no artigo $5^{\circ}$, incisos VI e VIII, e no artigo 19 , inciso $1^{\circ}$ (BRASIL, 1988).

Além disso, há uma série de tratados internacionais, como a Declaração Universal dos Direitos Humanos, a Convenção sobre os Direitos da Criança, o Pacto Internacional pelos Direitos Econômicos, Sociais e Culturais e a Convenção Americana de Direitos Humanos, dos quais o Brasil é signatário, que garantem a liberdade de crença e o respeito à diversidade cultural (DINIZ; LIONÇO; CARRIÃO, 2010).

Em especial, deve-se destacar a Declaração sobre a Eliminação de Todas as Formas de Intolerância e Discriminação Fundadas na Religião ou nas Convicções, aprovada em 25 de novembro de 1981 pelas Nações Unidas, que afirma, em seu preâmbulo, que a religião ou as convicções constituem elementos fundamentais para a constituição da vida daquelas e daqueles que as professam, devendo as convicções e a liberdade de crença serem garantidas e respeitadas integralmente. (BLANCARTE, 2003).

Contudo, só um regime de tolerância ou mesmo a garantia formal de liberdade religiosa não impedem a discriminação, como salienta Blancarte:

[...] en materia religiosa se debe hacer una distinción importante entre discriminación y tolerancia. Se puede ser tolerante con una religión, al mismo tiempo que se le discrimina. La instauración de un régimen de tolerancia hacia diversos cultos no es garantía de la eliminación de la discriminación legal, por no hablar de la social. Pero tampoco la libertad religiosa es sinónimo de no discriminación religiosa. (BLANCARTE, 2003, p.280).

Ademais, o fato de o texto constitucional contar com dispositivos que garantem secularismo e a liberdade da prática religiosa do ponto de vista jurídico, não significa que o Estado seja laico, ou seja, totalmente apartado da presença da religião na 
burocracia pública. Igualmente, tampouco implica que não haja uma religião - ou pensamento religioso - hegemônica, que atue como religiões públicas, forçando a que todas as outras apenas sejam toleradas como religiões privadas (CASANOVA, 1994).

A expressão "Estado laico", strictu sensu, não está presente em nenhuma linha do texto. Além disso, há uma expressa alusão a Deus no preâmbulo da Constituição o que pode ser interpretado como um reflexo da prevalência de proximidade entre Igreja e Estado.

No Brasil, são ilustrativos deste argumento, dentre outros, a presença e atuação institucional da Bancada Evangélica (cristã), ou todos os crucifixos (cristãos) pendurados em repartições públicas - inclusive na Câmara dos Deputados.

Os dispositivos que garantem a laicidade de um Estado, portanto, não são suficientes para assegurar que não haja discriminação religiosa. Mesmo porque a simples garantia de liberdade religiosa não exclui a existência de leis que criminalizam religiões minoritárias, ou seja, que não façam parte do arcabouço cristão.

As leis que criminalizaram as religiões afro-brasileiras eram explícitas nos ordenamentos jurídicos, penais e constitucionais que regiam o Brasil no período do império e mesmo após a proclamação da república e a instituição de um novo ordenamento jurídico. Apesar da garantia jurídica da liberdade religiosa, as religiões afro-brasileiras continuaram a ser criminalizadas, agora disfarçadas em uma roupagem evolucionista e higienista.

\section{A criminalização das religiões e práticas afro-brasileiras}

O período que inicia a colonização da região hoje conhecida como Brasil pelos portugueses foi caracterizado pelo atrelamento entre o Estado e a Igreja Católica, derivado da forma com que Portugal - que era um reino católico - regia seu império e suas colônias.

As primeiras normas jurídicas produzidas pelo Império português e estendidas ao Brasil foram derivadas das Ordenações Filipinas, que consistiam no ordenamento jurídico que regeu Portugal a partir de 1603 e que, no Brasil, teve vigência até 1916 (PAES, 2011). 
Revista Calundu - vol. 2, n.1, jan-jun 2018

As Ordenações Filipinas tinham evidente influência do catolicismo em sua formação e suas primeiras normas jurídicas produzidas pelo Império Português para regulamentar a escravidão obrigavam a conversão dos escravos ao catolicismo e a adoção de nome cristão (PAES, 2011); a proibição de manifestações coletivas dos africanos e seus descendentes, assim como a criminalização da feitiçaria ${ }^{3}$.

Em 1824, segundo o regime de padroado, a religião católica apostólica romana é estabelecida na Constituição Política do Império do Brasil, de 25 de março de 1824, como religião oficial do $E_{s t a d o}{ }^{4}$, todas as demais religiões são reduzidas ao culto doméstico e o Código Criminal do Império criminaliza as religiões não oficiais: “Art. 276. Celebrar em casa, ou edificio, que tenha alguma fórma exterior de Templo, ou publicamente em qualquer lugar, o culto de outra Religião, que não seja a do Estado.” (BRASIL, 1830)

Com a proclamação da república, em 1889, é formulada uma Constituição para o Brasil - a Constituição da República dos Estados Unidos do Brasil, promulgada aos 24 de fevereiro de 1891, que preconiza a separação entre o Estado e a Igreja ${ }^{5}$. Desde então essa separação ${ }^{6}$ é apresentada nas demais Constituições elaboradas no Brasil. (PAULY, 2004; BLANCARTE, 2008).

Todavia, o Código Penal da República (1890) é anterior a Constituição e seus artigos 156, 157 e 158 criminalizam a falsa prática ou prática ilegal da medicina, a prática do espiritismo e magia, e o curandeirismo, respectivamente. (GIUMBELLI,

\footnotetext{
${ }^{3}$ Ordenações Filipinas, disponível em http://www1.ci.uc.pt/ihti/proj/filipinas/15ind.htm

${ }^{4}$ Nos termos do artigo 5 da Constituição Imperial: "Art. 5. A Religião Catholica Apostolica Romana continuará a ser a Religião do Imperio. Todas as outras Religiões serão permitidas com seu culto doméstico, ou particular em casas para isso destinadas, sem fórma alguma exterior do Templo."

${ }^{5}$ São vários os dispositivos constitucionais de 1891 que permitem a interpretação da separação entre Estado e Igreja. Começando pelo texto do preâmbulo, que não menciona Deus ou realiza qualquer outra menção à religiosidade, e atingindo o corpo de dispositivos, cuja leitura permite a interpretação da separação. São exemplos: "Art 11 - É vedado aos Estados, como à União: [...] $2^{\circ}$ ) estabelecer, subvencionar ou embaraçar o exercício de cultos religiosos; [...]"; e "Art 72 - A Constituição assegura a brasileiros e a estrangeiros residentes no País a inviolabilidade dos direitos concernentes à liberdade, à segurança individual e à propriedade, nos termos seguintes: [...] A República não admite privilégios de nascimento, desconhece foros de nobreza e extingue as ordens honoríficas existentes e todas as suas prerrogativas e regalias, bem como os títulos nobiliárquicos e de conselho.; $\S 3^{\circ}$ - Todos os indivíduos e confissões religiosas podem exercer pública e livremente o seu culto, associando-se para esse fim e adquirindo bens, observadas as disposições do direito comum.; [...] $\S 5^{\circ}$ - Os cemitérios terão caráter secular e serão administrados pela autoridade municipal, ficando livre a todos os cultos religiosos a prática dos respectivos ritos em relação aos seus crentes, desde que não ofendam a moral pública e as leis.; § $6^{\circ}$ - Será leigo o ensino ministrado nos estabelecimentos públicos.; $\S 7^{\circ}$ - Nenhum culto ou igreja gozará de subvenção oficial, nem terá relações de dependência ou aliança com o Governo da União ou dos Estados. [...]".

${ }^{6}$ OBSERVAÇÃO: as Constituições continuam fazendo menção a um Deus único no texto dos preâmbulos.
} 
Revista Calundu - vol. 2, n.1, jan-jun 2018

2008; MAGGIE, 1992). Portanto, mesmo com a separação entre Estado e Igreja Católica, há a discriminação religiosa e consequente criminalização das religiões não hegemônicas.

Não é preciso muito para compreender que as pessoas criminalizadas por esses artigos eram negras e praticantes de religiosidade de origem africana haja vista que o cerne dessas práticas gira em torno de uma compreensão das plantas de usos medicinais e que estas são utilizadas nos tratamentos de pessoas que a elas busquem.

É interessante notar, entretanto, que havia uma hierarquização entre os praticantes do chamado alto espiritismo, associado a práticas kardecistas, e o baixo espiritismo relacionado à macumba e ao candomblé, sendo o primeiro mais tolerado que o segundo e hierarquicamente superior, como sugere a própria designação. (MAGGIE, 1992)

A função da criminalização da prática do espiritismo não é a extinção do mesmo, mas sim criminalizar a prática, reconhecê-la hierarquicamente de forma inferiorizada. $\mathrm{O}$ intuito é instituir o inimigo.

Em seu livro "Medo de feitiço: relações entre magia e poder no Brasil", Yvonne Maggie (1992) traz um panorama das criminalizações das religiões afro-brasileiras a partir dos artigos 156, 157 e 158 do Código Penal republicano de 1890, como acima referido. A autora afirma que o código penal de 1890 foi inovador ao criminalizar a prática ilegal da medicina, a prática da magia e espiritismo e o curandeirismo, sinalizando que estas não eram criminalizadas anteriormente.

A autora sustenta a argumentação de que o que era efetivamente reprimido pelos referidos artigos, eram as más práticas, seriam as práticas que teriam como fim a enganação e o lucro, o charlatanismo, baseada na categorização referente aos casos jurídicos por ela analisados e da formulação de Viveiros de Castro, juiz maranhense que defendia uma separação entre a má e a boa prática.

A meu ver, por traz do discurso higienista, positivista e comteano que sustenta tais decretos e que foi largamente utilizado na construção da república, há o racismo de toda e qualquer prática religiosa que não fosse a eurocentrada - cristã que, nesse caso, abre espaço para o espiritismo científico, tendo em vista a estruturação cristã e a larga influência do positivismo em sua formulação. 
Revista Calundu - vol. 2, n.1, jan-jun 2018

A opção de uma abordagem que não preza pelo eixo racial, indispensável para a leitura do contexto de criminalização de tais práticas, fez com que Maggie negligenciasse uma abordagem crítica do referido contexto. Apesar de inserir ao que ela denomina nova política repressiva, uma política higienista, proposta a partir da preocupação com a saúde da população, escapa a sua argumentação o ideário racista da mesma.

O advento das políticas higienistas está envolta de um ideário racista e finda por formular uma política de cunho modernista que prega a homogeneização da população através de uma imposição educacional e cultural preconizada pelo Estado.

Tendo em vista que a proclamação da república foi forjada em decorrência da abolição da escravidão no Brasil e que esta preza pela separação entre Igreja e Estado, os artigos que criminalizam as religiões afro-brasileiras são derivados da necessidade de se separar quais eram as práticas religiosas reconhecidas pelo Estado e quais não eram.

O Estado se ausenta da relação com a Igreja Católica, mas não deixa de determinar quais práticas religiosas são consideradas religiões e como essas serão praticadas. (MAGGIE, 1992)

O código penal atual, que data de 1940, herdou alguns dos artigos do código penal anterior, de 1890, sendo dois deles do processo de criminalização da prática de curandeirismo e do crime de charlatanismo:

\author{
Charlatanismo \\ Art. 283. Inculcar ou anunciar cura por meio secreto ou infalível: \\ Pena - detenção, de três meses a um ano, e multa, de um a cinco contos de réis. \\ Curandeirismo \\ Art. 284. Exercer o curandeirismo: \\ I - prescrevendo, ministrando ou aplicando, habitualmente, qualquer substância; \\ II - usando gestos, palavras ou qualquer outro meio; \\ III - fazendo diagnósticos: \\ Pena - detenção, de seis meses a dois anos. \\ Parágrafo único. Se o crime é praticado mediante remuneração, o agente fica \\ tambem sujeito à multa, de um a cinco contos de réis. (BRASIL, 1940)
}

Portanto, a criminalização das religiões afro-brasileiras é passível de ocorrer dentro do enquadramento dos artigos anteriores já que, como dito anteriormente, se trata de uma prática religiosa que compreende a saúde como um bem importante e que preza para a sua existência de acordo com saberes medicinais calcados em um amplo conhecimento de plantas medicinais e de uso culinário. 
Revista Calundu - vol. 2, n.1, jan-jun 2018

O próprio fato de que religiões afro-brasileiras tenham sido criminalizadas sob a acusação de curandeirismo enquanto práticas religiosas pentecostais, que diariamente são retratadas nos canais televisivos, inculcam a cura através do processo de cura pelo espírito santo, nunca terem sido condenadas, demonstra as características racistas de tais leis ${ }^{7}$.

Soma-se a repressão e as formas de controle às religiões afro-brasileiras o registro obrigatório em delegacias de polícias dessas religiões e a permissão para a concretização de festas em terreiros, como também o pagamento de uma taxa por essas religiões a delegacia. Essa prática foi exercida até recentemente, pois a revogação dessa lei é posterior a 1976, sendo o estado da Bahia o primeiro a ter o decreto revogado:

\begin{abstract}
O indicador final e sintomático do status das religiões afro-brasileiras na sociedade do país está na exigência que dura séculos, de serem os seus templos as únicas instituições religiosas no Brasil com registro obrigatório na polícia. Esta medida de caráter compulsório continua vigorando atualmente em todos estados da República exceto na Bahia, cujo Governador, um ano atrás, revogou aquela exigência pelo decreto 25.095, de 15 de janeiro de 1976. (NASCIMENTO, 1978, p. 104)
\end{abstract}

Atualmente, apesar de avanços na legislação com relação à garantia de liberdade religiosa e aos direitos a ela referentes, ainda temos um cenário de discriminação e criminalização das religiões afro-brasileiras. O caso mais expressivo se trata da criminalização dos sacrifícios de animais por religiões afro-brasileiras sob a justificativa de maus tratos aos animais ${ }^{8}$. Além de ser infundada tal afirmação, já que não há não forma de maus tratos ao animal a ser sacrificado ${ }^{9}$, expressa mais uma vez o racismo de tal lei ao ser uma proibição específica ao sacrifício nas referidas religiões enquanto outras denominações religiosas, como o judaísmo e o islamismo, não passam por situações de proibições ou coibições semelhantes.

É importante salientar ainda que, atualmente, várias outras leis são utilizadas para a criminalização das religiões afro-brasileiras, como é o caso da lei do silêncio, ou

\footnotetext{
7 Mais sobre a questão das condenações as práticas afrorreligiosas: SCHRITZMEYER, Ana Lúcia Pastore. Sortilégio de saberes: curandeiros e juízes nos tribunais brasileiros (1900-1990). São Paulo: IBCCRIM, 2004. 204 p.

${ }^{8}$ Derivada de uma legislação do estado do Rio Grande do Sul concedida pelo Tribunal de Justiça do estado, tramita no Supremo Tribunal Federal uma ação do Ministério Público do Rio Grande do Sul que pede a inconstitucionalidade do abate religioso previsto na lei 12.131/04-RS. O Recurso Extraordinário 494601 ainda será discutido.

${ }^{9}$ Para ver mais sobre o assunto: FLOR DO NASCIMENTO, 2015
} 
ainda a lei fundiária devido à falta de regularização imobiliária de muitos terreiros (GUALBERTO, 2011).

Essas criminalizações através de leis que não vinculam as religiões afro diretamente em seu conteúdo deve ser interpretada como uma das várias articulações de camuflagem do racismo em nossa sociedade que continua a negar sua existência (FLOR DO NASCIMENTO, 2017).

Exemplo disso foi o fato ocorrido aos 27 de fevereiro de 2008, dia em que o terreiro Oyá Onipó Neto foi parcialmente destruído, com a autorização do então prefeito de Salvador, João Henrique (PMDB/BA), sob a alegação de irregularidade fundiária. A Mãe de Santo responsável pelo terreiro, Rosalice do Amor Divino, alegou que nunca havia recebido notificação sobre a referida demolição. $O$ fato desencadeou uma grande movimentação das entidades sociais em defesa do terreiro e acarretou em um pedido de desculpas do prefeito João Henrique (GUALBERTO, 2011, p. 126-127). Atualmente, o terreiro encontra-se reconstruído.

Casos como esse não são incomuns e mostram as fragilidades que essas religiões têm que enfrentar dentro do ordenamento jurídico atual.

\section{Perseguição política, mídia e polícia}

Durante os anos em que a mídia era representada majoritariamente pela via impressa, é possível perceber como os jornais, a partir da adoção de uma postura política atrelada ao desenvolvimentismo moderno, "eram um apêndice da política visto que seu surgimento está diretamente ligado a interesses dos grupos oligárquicos" (PACHECO, 2015, p. 9). Referidos jornais se vincularam a uma forma frequente de atuação que buscava ser identificada como guardiã da moral da sociedade e dos bons costumes, discriminando de forma racista as religiões afro-brasileiras, assim como todos os símbolos, performances, festas e crenças que tivessem origens africanas.

Ao referenciar o grande ataque às religiões afro-brasileiras em Maceió, o "Quebra de Xangô" em 1912, devido a uma disputa política entre os poderes oligárquicos da região que acabou com a expulsão do então governador Euclides da Mata e uma perseguição política, encabeçada por jornais oposicionistas, que associavam o então governador à prática de cultos africanos, findou por promover no dia $1^{\circ}$ de fevereiro de 1912 a destruição de vários terreiros e estabelecer a proibição dos cultos 
Revista Calundu - vol. 2, n.1, jan-jun 2018

afro-brasileiros, o que levou ao exercício da prática do chamado Xangô rezado baixo. Essa proibição durou longos anos e marcou profundamente as comunidades do Xangô dessa região. (RAFAEL, 2004; PACHECO, 2015)

[...] é, associado aos adjetivos fetiche ignorante, antros endemoniados, feitiçaria barata vê-se a declaração de que Euclides Malta construiu uma oligarquia longa graças, justamente, ao apoio que tinha de tais Casas e que essa ligação desorganizava o Estado, a polícia e as demais esferas do poder. (PACHECO, 2015, p. 91)

O trabalho de Rafael (2004) traz a forte associação da perseguição das religiões afro-brasileiras, nesse caso em específico do Xangô em Alagoas, e aos conflitos políticos das oligarquias. Nesse mesmo sentido, Santos (2009) mostra como essa trama não é específica de Alagoas, tendo também reverberação nas disputas políticas das oligarquias do recôncavo baiano.

Tais disputas políticas foram largamente abordadas pelos jornais do estado de Alagoas e puderam promover a forma estereotipada com que as religiões afrobrasileiras ficaram conhecidas:

\begin{abstract}
as expressões linguísticas difundidas popularmente sobre as religiões de matriz africana, se tornam o principal mote de relação para com as mesmas. E, à medida que tais expressões são corroboradas oficialmente, como no caso dos jornais impressos, a relação entre a população racista e tais Casas religiosas, que antes era de caráter privado, ganha legitimidade de ação pública racista.

A estratégia política de associar a figura do oligarca Euclides Malta às Casas de Xangô, misturando e intensificando o descontentamento com ambos, favoreceu uma explicitação hostil frente ao Xangô, ao passo que assumir a hostilidade ao oligarca era o comportamento esperado (PACHECO, 2015, p. 90)
\end{abstract}

Santos (2009) demonstra, através do noticiário do jornal A Ordem, jornal de maior circulação no interior do Estado baiano, assim como demais jornais encontrados nos arquivos baianos, no período delimitado pelo autor, entre 1901 a 1934, como as oligarquias políticas expressavam suas ambições e agiam de forma a proteger o seus interesses ao passo em que atacavam as religiões afro-brasileiras, em especial o jornal em questão. (p. 22-23)

Mediante cuidadoso levantamento feito nos jornais da época foi possível notar um discurso elucidativo sobre o olhar de setores letrados a respeito das noções de civilização que informavam e justificavam suas posições. Aparentemente elaborada por representações fragmentadas, elas acabam por construir um quadro mais ou 
Revista Calundu - vol. 2, n.1, jan-jun 2018

menos coerente do período estudado, mostrando como o discurso civilizador dissimulava o racismo que trespassava as relações sociais (SANTOS, 2009, p. 22)

As noções que balizavam as discussões, argumentações, opiniões e reivindicações nestes meios midiáticos tiveram base na adoção de uma política modernista que prezava pela modernização urbana; repressão da vadiagem; repressão aos divertimentos populares que feriam a moral cristã; a valorização de padrões culturais europeus; o expurgo das heranças africanas, o qual estaria vinculado o sucesso da implementação da civilização (SANTOS, 2009, p. 22-25).

A notícia vinculada ao jornal A Ordem, de 22 de julho de 1914, é exemplo dos ideais representados por tal jornal:

Chega-nos reclamações de um fato triste e deponente que se está dando em plena cidade. À rua Martins Gomes, no prédio n. ${ }^{\circ}$ 67, há, quase diariamente, as encenações da missa negra dos africanos, transplantada infelizmente para os nossos costumes antes da lei Euzébio de Queiroz, que aboliu o tráfico de escravos. Essas encenações são sempre acompanhadas de incomodativo e ensurdecedor candomblé.

E porque a época que atravessamos traz o rótulo de Civilizemo-nos! Bem será que o sr. major delegado, cujas atribuições são manter a ordem em bem da civilização indígena, volva a sua vista perscrutadora para as missas negras da rua Martins Gomes. (SANTOS, 2009, p. 25)

"É interessante notar que o jornal que frequentemente identificava o candomblé com a degeneração da família, da sociedade e até mesmo da raça, representando-o como o lugar de bródios e orgias" (SANTOS, 2009, p. 25), ao que acrescento o forte apelo a polícia, acima retratado pela figura do delegado, como se o jornal fosse uma espécie de paladino em busca da moral e dos bons costumes da sociedade.

Petean (2011), também aborda o racismo incidido sobre as religiões afrobrasileiras através do jornal Diário da Manhã, de Ribeirão Preto, São Paulo, no qual eram exigidas providências ao combate de tais religiões. $\mathrm{O}$ autor associa tais investidas do referido jornal como contribuinte de uma imagem negativa sobre as religiões afrobrasileiras na cidade de Ribeirão Preto. (p. 23)

Em nossa edição de sábado tivemos a opportunidade de chamar a attenção do dr. Raymundo Moreira da Cunha, o novo delegado da cidade, para o assoberbante desenvolvimento que vem tendo, em nossa cidade, a prática nefanda do falso espiritismo, do curandeirismo e outras tantas mazellas, flagrante desprestígio para o índice de cultura e progresso de Ribeirão Preto. Na allegação de pretextos ridículos, invocando a necessidade de agradar a "paes de santos" e protectores, macumbeiros, cartomantes e falsos espíritas exploram sordidamente a crendice simplória de pessoas incautas, extorquindo-lhes quantias que, embora à primeira vista pareçam 
Revista Calundu - vol. 2, n.1, jan-jun 2018

insignificantes, tornam-se mais tarde, de algum vulto, pela sua repetida freqüência. (Diário da Manhã, 21 de julho de 1936) (PETEAN, 2011, p. 23)

Os leitores têm visto: - esta folha, com o propósito de collaborar na acção policial na repressão aos macumbeiros e outros illaqueadores da fé, da crendice alheia, todos elles na funcção damnosa de propagar o mal. (Ribeirão Preto, Diário da Manhã, domingo, 26 de julho de 1936) (PETEAN, 2011, p. 24)

A citação acima mostra a interação que existia entre os meios midiáticos, representados nesse caso por jornais, e as ações de repressão policial contra as religiões afro-brasileiras.

MACUMBEIROS, CURANDEIROS \& CIA. SANEAR, É A ORDEM. E NESSA MISSÃO AS AUTORIDADES POLICIAIS DEVEM ATTINGIR, TAMBÉM, AS CHAMADAS FAZEDORAS DE ANJOS.

Sanear! Sanear a cidade de todos os seus péssimos elementos, é a ordem do momento. Por isso estão as nossas autoridades policiaes empenhadas em forte campanha que venha pôr um termo á nefasta exploração da crendice e superstição populares, que venha eliminar do convívio social riberopretano toda essa canalha sórdida formada pelos macumbeiros, curandeiros, chiromantes, pytonisas, etc.

Sanear, é a ordem!

Dahi a atividade incessante que, nesse sentido, vem empregando o dr. Raymundo Moreira da Cunha, delegado da, que tem feito localizar vários centros, para onde a bruxaria, a macumba, o falso espiritismo e outra actividades illicitas e malsãs, falsamente rotuladas attraem grande número de pessoas, umas pela sua simplicidade e ignorância. Muitas por serem verdadeiros papalvos, todas, porem, deixando-se explorar vilmente, sob ridículas allegações. (Diário da Manhã, Ribeirão Preto, 28 de julho de 1938) (PETEAN, 2011, p. 25)

A última citação consegue exemplificar de maneira sintética as relações entre a posição política, a convocação da atuação policial, ou seja, a atuação estatal, e a criminalização das religiões afro-brasileiras sob a argumentação higienista que embasava os artigos que eram utilizados para a criminalização dessas religiões, como citado na sessão anterior desse artigo.

Atualmente, o vínculo entre atuação política e mídia está atrelado, principalmente, as grandes corporações religiosas proprietárias de canais televisivos, como também autorizadas, através da concessão de horário de algumas emissoras, há uma programação religiosa proselitista e jornais impressos que disseminam de forma frequente e racista ataques às religiões afro-brasileiras através de seu proselitismo religioso.

O dia de combate à intolerância religiosa, 21 de janeiro, é uma data que não foi escolhida por acaso, mas como uma homenagem a Mãe Gilda, do Ilê Axé Abassá de 
Revista Calundu - vol. 2, n.1, jan-jun 2018

Ogum, pelo dia de sua morte, 21 de janeiro de 2000, em decorrência de um caso de discriminação efetivado pela Igreja Universal do Reino de Deus.

A imagem de Mãe Gilda foi utilizada pelo jornal impresso da Igreja Universal do reino de Deus, em outubro de 1999, sem a sua autorização, e abaixo de sua imagem continham os dizeres: "Macumbeiros charlatões lesam o bolso e a vida dos clientes".

A aparição da imagem de Mãe Gilda no jornal Folha Universal trouxe vários problemas, o mais evidente deles seria a vinculação de sua imagem com o ato de charlatanismo, a discriminação com relação às religiões afro-brasileiras, e outras consequências vieram a partir de sua associação equivocada com a produção do próprio jornal. Todos esses episódios somados causaram grande pesar a vida de Mãe Gilda que veio a falecer após assinar uma procuração em que dava ao seu advogado a permissão de processar a Igreja Universal do Reino de Deus por seu ato. A filha biológica de Mãe Gilda e também herdeira do Ilê Axé Abassá de Ogum, Mãe Jaciara de Oxum, atribui ao episódio de discriminação a morte de sua mãe.

O caso correu judicialmente por alguns anos e em 06 de julho de 2005 o Tribunal de Justiça da Bahia confirmou a sentença, em decisão unânime, de condenação da Igreja universal do Reino de Deus à indenização por danos morais a família de Mãe Gilda. A sentença foi comemorada pela comunidade de terreiro como uma vitória do povo de santo. (GUALBERTO. p. 110, 2011)

Recentemente as comunidades de terreiro puderam comemorar mais uma vitória contra a emissora Record no dia 5 de abril de 2018. Com o embasamento dos discursos de ódio, de preconceito e violação das religiões afro-brasileiras perpetrados pela Rede Record de Televisão e pela extinta Rede Mulher, comprada pela Record, a ação foi movida em 2004 pelo Ministério Público Federal acionado pela Procuradoria Regional dos Direitos do Cidadão de São Paulo em conjunto com Centro de Estudos das Relações de Trabalho e da Desigualdade (CEERT) e pelo Instituto Nacional de Tradição e Cultura Afro Brasileira (Intercab). Depois de 14 anos, e ainda sob a possibilidade de recursal no Supremo Tribunal Federal, a determinação da exibição de uma programação de 16 horas realizada em horário nobre na Rede Record com conteúdo elaborado pelas religiões afro-brasileiras mostra uma vitória de toda a comunidade de terreiro, assim 
Revista Calundu - vol. 2, n.1, jan-jun 2018

como evidencia a resistência das mesmas contra as violências e violações de seus direitos ${ }^{10}$.

\section{Discriminações no contexto escolar}

As discriminações no contexto escolar são frequentes e tem por base a reprodução dos preconceitos que permeiam nossa sociedade. A discriminação das religiões afro-brasileiras nesse contexto pode ser ainda mais evidente devido à obrigatoriedade do ensino religioso em escolas públicas.

Reintroduzido pelo decreto 19.1941 de 1931, após a sua extinção com o advento da República, pela atuação do Ministro da Educação e Saúde, Francisco Campos, em articulação com a hierarquia católica (PAULY, 2004), e posteriormente incorporado pela constituição de 1934, artigo 153, (Brasil, 1934), o ensino religioso volta a tomar posição dentro da educação pública e se mantem até os dias atuais.

Após a inclusão do ensino religioso na Constituição de 1988, com o artigo 210, $\S 1^{\circ}$; é a Lei de Diretrizes e Bases da Educação (LDB), de 1996 e posterior reformulação em 1997, quem dita a forma com que o ensino religioso será ministrado.

Em seu artigo 33, reformulado pela lei 9475/97 liderada pelo deputado padre Roque Zimmermann (PT/PR) influenciado pelo lobby eclesiástico (PAULY, 2004) ${ }^{11}$, a LDB garante a obrigatoriedade da oferta do ensino religioso e o caráter facultativo da matrícula na disciplina, além de vedar quaisquer formas de proselitismo religioso. Além disso, o Estado transfere para as Secretarias de Educação estaduais e municipais a responsabilidade de formação de um conteúdo para este ensino que deve ser elaborado juntamente com entidades civis ${ }^{12}$.

\footnotetext{
${ }^{10}$ Informações disponíveis em : https://mundonegro.inf.br/ppopulacoes-de-matrizes-africanas-vencempor-unanimidade-acao-contra-rede-record/; http://politica.estadao.com.br/blogs/fausto-macedo/religioesafro-brasileiras-ganham-direito-de-resposta-na-record/; https://www.cartacapital.com.br/blogs/dialogosda-fe/a-rede-record-e-o-direito-de-respostas-as-religioes-de-matriz-africana

${ }^{11}$ A citação do termo lobby eclesiástico e sua influencia na mudança do artigo 33 da LDB está presente na obra de Evaldo Luis Pauly: O dilema epistemológico do ensino religioso (2004)

12 Para a elaboração destes conteúdos foram criadas o Fórum Permanente do Ensino Religioso (FONAPER), que é uma associação voluntária; e os Conselhos para o Ensino Religioso (Coner), que em alguns estados já eram articulados e atuavam juntos ao estado na implementação do ensino religioso. As duas entidades foram, e muitas ainda são, fortemente marcadas pela presença de entidades e representantes cristãs e a não incorporação de demais entidades religiosas. (Dickie, 1996; Diniz;Lionço; Carrião, 2010)
} 
Contudo, o veto ao proselitismo religioso foi colocado em questão depois que o Supremo Tribunal Federal se posicionou de forma contrária a Ação Direta de Inconstitucionalidade (ADI) 4439, demandada pela Procuradoria Geral da República (PGR), que pedia a desvinculação do ensino de religiões específicas e que fosse proibido o ensino religioso ministrado por representantes de instituições religiosas. Com a rejeição da ADI 4439 e a aprovação do modelo confessional coloca em cheque o veto ao proselitismo ${ }^{13}$.

Mesmo antes do atual posicionamento do STF com relação ao modelo confessional, em 27 de setembro de 2017, apesar da existência do veto ao proselitismo religioso nas escolas públicas, na prática isso não é totalmente alcançado, (CAVALIERI, 2007). Ademais, o caráter facultativo da disciplina também não é garantido visto a dificuldade das instituições de ensino em criar outras disciplinas ou a ausência de professores, devido a carência dos mesmos no sistema de ensino público, para ministrar uma atividade que seja realizada no mesmo horário em que a de ensino religioso.

Portanto, não é incomum o aparecimento de notícias que divulgam a discriminação e o desrespeito aos direitos de alunos e alunas que não são de confissões cristãs.

$\mathrm{O}$ caso se agrava ainda mais quando se considera que o ensino religioso nas escolas públicas aumenta a discriminação. Foi o que constatou a jornalista Stela Guedes Caputo, em sua pesquisa de doutorado que descreve a realidade das crianças adeptas ao Candomblé no contexto das escolas públicas do Rio de Janeiro ${ }^{14}$.

A autora destaca, sobretudo, a opinião dos professores de Umbanda que lecionam ensino religioso: a dificuldade de encontrar livros e outros materiais escolares direcionados para esse trabalho que não sejam produzidos por católicos e evangélicos. Também não são oferecidas, conforme estabelece a Lei, alternativas para quem não quer assistir às aulas e, além disso, orações católicas e/ou evangélicas são tratadas como "universais", sendo muito comum encontrar, nesse contexto, a tentativa de conversão dos alunos ou, pior, a negação e o silenciamento quanto à existência de adeptos de outros credos. (RUSSO; ALMEIDA, 2016, p. 473)

\footnotetext{
${ }^{13}$ A Ação Direta de Inconstitucionalidade requerida pela Procuradoria Geral da República pode ser lida na integra em: http://www.stf.jus.br/portal/geral/verPdfPaginado.asp?id=635016\&tipo=TP\&descricao=ADI\%2F4439

${ }_{14}$ Educação nos terreiros e como a escola se relaciona com as crianças do candomblé. Stela Guedes Caputo. (2012)
} 
Em setembro de 2014 um aluno de doze anos, da Escola Municipal Francisco Campos, da Zona Norte do Rio de Janeiro, foi impedido de entrar na referida escola pela direção da mesma por portar guias ${ }^{15}$ referentes à sua religião, o candomblé.

Em Rondônia uma aluna de oito anos, adepta de religião afro-brasileira, relatou sofrer insultos e xingamentos dentro da escola, proferidos por sua professora que era evangélica ${ }^{16}$.

O relato de dois psicólogos que atuavam como supervisores de estágio em psicologia escolar afirmam que relatos que descrevem a discriminação religiosa no ambiente escolar são frequentes e que é um desafio pensar na atuação dos psicólogos escolares frente a essas discriminações tendo em vista que:

compartilhamos um imaginário coletivo habitado por estereótipos negativos de África, africanos, seus descendentes e tudo o mais que diga respeito a eles. Por isso, discursos psicológicos superficiais e estereotipados dificilmente atingem o âmago do problema. (FRIAS; RIBEIRO, 2016, p. 212)

O estudo acima referido tem por base o relato de um aluno do ensino fundamental da rede pública:

\begin{abstract}
Bruno é um menino de oito anos cujos pais são adeptos da religião tradicional iorubá. Na semana passada, esteve ausente porque estava sendo iniciado em Ifá. Retorna hoje aos bancos escolares, orgulhoso de ser agora um iniciado de Ifá, integrante de um coletivo internacional de iniciados nesse Orixá, divindade da sabedoria do povo iorubá. Exibe, com respeito e reverência, a marca de sua pertença a esse coletivo: uma discreta pulseirinha de contas marrons alternadas com contas verdes. De resto, ele aparece aos olhos de todos como o mesmo menino de sempre. A professora aproxima-se dele, observa a pulseirinha, dirige-se ao armário da classe, pega uma tesoura, volta para perto de Bruno, corta a pulseira e, com gestos dramáticos e expressão facial dura, a atira, com raiva, no cesto de lixo. Os coleguinhas assistem à cena e acham muito engraçado. (FRIAS; RIBEIRO, 2016, p. 211)
\end{abstract}

Ao que seguem: "Evidentemente, o gesto de repulsa da professora diante de um símbolo sagrado africano finca raízes em sua intolerância religiosa, sim, mas também em relação à diversidade étnico-racial porque, afinal de contas, 'macumba é coisa de preto!'” (FRIAS; RIBEIRO, 2016, p. 212)

\footnotetext{
${ }^{15}$ Guias são fios de contas feitos de miçangas que representam os orixás, voduns, inquices e outras entidades presentes no complexo religioso afro-brasileiro.

${ }^{16}$ Notícia disponível em na revista Fórum online: http://www.revistaforum.com.br/blog/2015/02/pequenos-fieis-quando-intolerancia-religiosa-atingecriancas/ Acesso 12/03/2015 - 19:50.
} 
O trabalho de Eduardo Quintana (2013), intitulado "Intolerância Religiosa na Escola: o que professoras filhas de santo tem a dizer sobre esta forma de violência", foi construído a partir de uma análise de sua experiência como docente, assim como no depoimento de três professoras, que são também filhas de santo, aponta para a realidade da discriminação das religiões afro-brasileiras no contexto escolar e o fato de que tanto alunos e alunas, como professores e professoras, se vêm impelidos, muitas vezes, em negar a sua filiação religiosa por terem medo de serem discriminados. (QUINTANA, 2013, p.128)

Nos três depoimentos há a afirmação de que os adeptos das religiões afrobrasileiras sofrem com a discriminação e o preconceito:

\begin{abstract}
Sobre como a escola trata os praticantes de religiões afro-brasileiras, Graça afirma que há muito preconceito, fazendo com que eles se sintam intimidados em assumir sua orientação religiosa. Ela assegura que essa lógica se replica na relação entre pares. Nos últimos anos, ela tem observado que, nas escolas onde há maior número de professores evangélicos, os docentes que praticam o candomblé se sentem discriminados, o que acontece com a anuência dos diretores. (QUINTANA, 2013, p. 130)
\end{abstract}

A professora afirma, então, que o espaço onde ela aprendeu a lidar com a diferença foi em uma religião afro-brasileira, através de sua vivência nessa religião:

Nesse sentido, Graça afirma que o candomblé é uma grande escola, pois ensina aos seus praticantes que "as pessoas têm qualidades e defeitos" e, por isso, não devemos emitir juízo de valor sobre elas. Em sua opinião, é o candomblé e não a escola que tem ensinado aos seus praticantes a lidar com a diferença, a se relacionar com as outras religiões. (QUINTANA, 2013, p. 130)

\title{
As implicações cristãs neopentecostais
}

Houve um crescente número de ataques e perseguições exercidas pelos neopentecostais nas últimas décadas, principalmente após a década de 80 (REINHARDT, 2006; SILVA, 2007). Casos de discriminação, caracterizados por meio de cultos evangélicos, que eram anteriormente irrisórios passaram a ocupar o espaço público devido à abrangência e gravidade dos mesmos, assim como a maior ocupação deste espaço pelos neopentecostais o que passa incitar uma disputa pelo domínio do mesmo. Esses ataques são caracterizados por meio de cultos com vieses proselitistas; agressões físicas a filhos e filhas de santo, como também aos espaços dos terreiros; 
Revista Calundu - vol. 2, n.1, jan-jun 2018

ataques às representações públicas das religiões afro-brasileiras, em festas públicas ou a monumentos em espaço público; e ataques políticos devido ao vínculo de políticos a filiações evangélicas. (SILVA, 2007, p. 9-10)

O embasamento dos discursos proselitistas das religiões neopentecostais está fortemente embasado com a questão da existência polarizada do bem e do mal no mundo espiritual. A partir dessa polarização o lado associado ao bem, o lado positivo, seria retratado por Deus e o lado mal, negativo, estaria associado à figura do diabo. $\mathrm{O}$ que ocorre é que devido a essa interpretação tudo o que não é derivado da tríade: deus, pai; Jesus, filho, e o espírito santo, é associado ao mal, ou seja, ao diabo.

A partir dessa interpretação e embasados em uma busca pela conversão dos povos da terra, encarando o papel missionário e salvacionista cristão em suas últimas consequências, muitos dos adeptos e adeptas de tais religiões terminam por promover ataques às religiões afro-brasileiras tendo como justificativa uma espécie de guerra santa que já vem se desenrolando a alguns anos no Brasil e também em alguns países da América Latina, devido a expansão de ambas religiões a países como Argentina, Uruguai e Chile. (SILVA, 2007)

São muitos os ataques registrados, como:

No Rio de Janeiro, umbandistas do Centro Espírita Irmãos Frei da Luz foram agredidos com pedradas pelos frequentadores de uma Iurd situada ao lado desse Centro, na Abolição . Uma adepta da Tenda Espírita Antônio de Angola, no bairro do Irajá, foi mantida por dois dias em cárcere privado numa igreja evangélica em Duque de Caxias, com o objetivo de que esta renunciasse à sua crença e se convertesse ao evangelismo.

Em Salvador, tida como a "capital da macumbaria" ou a "Sodoma e Gamorra da magia negra" pelos neopentecostais, uma iniciada no candomblé teve sua casa, no bairro de Tancredo Neves, invadida por trinta adeptos da Igreja Internacional da Graça de Deus, que jogaram sal grosso e enxofre na direção das pessoas ali reunidas durante uma cerimônia religiosa. Essas substâncias também são atiradas em automóveis que possuem colar de contas (guias) pendurado no espelho retrovisor (SILVA, 2007, p. 12).

Quando se trata de eventos públicos produzidos pelas religiões afro-brasileiras:

Durante uma festa de Iemanjá ocorrida na praia do Leme, Rio de Janeiro, neopentecostais pregaram contra a cerimônia com auxílio de alto-falantes e destruíram os presentes ofertados à entidade, associada ao mar. O mesmo ocorreu durante uma festa de erês (entidades infantis) realizada na Quinta da Boa Vista, quando os neopentecostais quebraram imagens e queimaram roupas de santo. (SILVA, 2007, p.14) 
Revista Calundu - vol. 2, n.1, jan-jun 2018

Com relação aos símbolos dessas religiões expostos em ambientes públicos, como o caso das estatuas de orixás no dique do Tororo, em Salvador, e a prainha em Brasília, além de terem uma série de críticas relacionadas a exposição pública de símbolos "demoníacos" (SILVA, 2007), são frequentemente alvo de destruição e depredação, como evidencia essa notícia de 26 de maio de 2006:

Nesta semana foram registrados mais casos de inflexibilidade religiosa com as esculturas dos Orixás encontrados na Prainha do Lago Sul. Desde o ano passado, tais obras vêm sendo destruídas e desrespeitadas pela população. Desconfia-se de que essas ações derivam de outras religiões, por existir uma aversão as seitas umbanda e candomblé. ${ }^{17}$

Essa é datada de 29 de dezembro de 2015:

Representantes de religiões de matrizes africanas do Distrito Federal denunciaram mais um ataque de intolerância contra símbolos sagrados. Um grupo de três pessoas tentou arrancar o cajado da estátua de Oxalá na Praça dos Orixás, na Prainha do Lago Paranoá. O ato de vandalismo aconteceu dias antes de uma das mais importantes comemorações dos praticantes. Um morador de rua impediu que a peça fosse completamente destruída. ${ }^{18}$

Ou ainda em 11 de abril de 2016:

Representantes de religiões de matrizes africanas do Distrito Federal denunciaram mais um ataque de intolerância contra um símbolo sagrado. Na madrugada desta segunda-feira (11/4), por volta de 0h, um grupo de criminosos ainda não identificado, incendiaram uma das estátuas, na Praça dos Orixás, na Prainha do Lago Paranoá. A estátua de Oxalá ficou totalmente destruída. ${ }^{19}$

O que embasa esse confrontos, essa situação de guerra santa reivindicada pelos neopentecostais é o racismo presente em sua construção proselitista.

Segundo Petean (2011) o discurso da Igreja Universal do Reino de Deus (IURD), está finamente embasado em uma ideia evolucionista que resgata práticas do ideal de branqueamento (p. 15). O argumento defendido pelo autor em seu trabalho

\footnotetext{
${ }^{17}$ Artigo informativo de autoria de Suely Frota, disponível em: http://horariodebrasilia.blogspot.com.br/2006/05/

${ }^{18}$ Reportagem do jornal Correio Brasiliense, disponível em: http://www.correiobraziliense.com.br/app/noticia/cidades/2015/12/29/interna_cidadesdf,512294/grupode-vandalos-destroi-estatua-de-orixa-na-prainha-do-lago-paranoa.shtml

${ }^{19}$ Reportagem do jornal Correio Brasiliense, disponível em: http://www.correiobraziliense.com.br/app/noticia/cidades/2016/04/11/interna_cidadesdf,526657/vandalos -ateiam-fogo-em-imagem-de-orixas-na-prainha-do-lago-sul.shtml
} 
Revista Calundu - vol. 2, n.1, jan-jun 2018

intitulado: “O Racismo como Questão Epistemológica: uma interpretação do discurso religioso evolucionista da Igreja Universal do Reino de Deus" é de que as noções racistas presentes na ideologia do branqueamento e nas higienistas embasam a referência teológica dos discursos proferidos pelos representantes dessa nominação religiosa:

partimos da hipótese de que o discurso da Igreja Universal do Reino de Deus construiu uma lógica muito particular combinando com elementos do discurso calvinista, presente na tradição da política econômica dos EUA, com as práticas de higienização e branqueamento que já fizeram parte das políticas públicas do Estado nacional. (PETEAN, 2011, p. 15)

A IURD foi criada tendo como centro argumentativo de sua teologia a crença no deus cristão em evidente oposição as religiões afro-brasileiras. Assim, toda a referência de mal que possa impedir o desenvolvimento de um adepto dessa nominação religiosa é derivada de um impedimento espiritual maligno associado a algumas das entidades espirituais das religiões afro-brasileiras.

Assim como a Igreja Universal do Reino de Deus, as religiões neopentecostais apresentam como características:

i) A influência da 'teologia da prosperidade', que potencializa as dimensões econômicas não ascéticas do cristianismo pela ênfase da realização cotidiana de milagres tendo em vista uma 'vida abundante'; ii) a liberalização dos 'usos e costumes' que desmonta o controle estrito do comportamento [...] e iii) o papel central ocupado em sua cosmologia pelas entidades demoníacas, de onde resulta o frequente recurso ritual ao exorcismo e os intensos conflitos com as religiões mediúnicas, principalmente as afro-brasileiras, como o candomblé, a umbanda e a quimbanda. (REINHARDT, 2006, p, 22)

A especificidade da Igreja Universal do Reino de Deus é que esta foi construída com uma base central de oposição as religiões afro-brasileiras sendo a elas atribuídas todas as formas de personificação material e espiritual atreladas ao mal, ou seja ao demônio. A sua posição extrema de ataque as religiões afro-brasileiras fez com que algumas denominações religiosas se colocassem contrárias a sua atuação ao mesmo tempo em que passou a influenciar outras denominações religiosas evangélicas. (REINHARDT, 2006)

O fato é que, a partir do estabelecimento de única detentora da verdade e a consequente inferiorização das religiões afro-brasileiras, torna-se evidente o racismo epistêmico desenvolvido por essas denominações religiosas. 
Tomando como base a construção da Igreja Universal do Reino de Deus e as demais denominações religiosas por ela influenciadas, acredito que o preconceito e a discriminação das religiões afro-brasileiras não é respaldado por uma falta de conhecimento ou ignorâncias de tais religiões. O que existe é um atrelamento hierarquizado e inferiorizante a todo o universo religioso afro-brasileiro, sendo este um ato deliberado que sustenta a criação do inimigo dentro de tais religiões.

A firme convicção que têm os evangélicos, principalmente os neopentecostais, de que somente sua visão religiosa é a certa, é a verdadeira, já implica numa concepção preconceituosa e racista na qual as religiões afro-brasileiras são taxadas de feitiçaria, bruxaria, macumba e outros termos depreciativos. (GUALBERTO, 2011, p. 16)

Vários são os estudos que trazem a temática da discriminação às religiões afrobrasileiras a atuação das religiões neopentecostais. Entretanto, este é um dos cenários das discriminações sofridas, considerando que grande parte do racismo religioso que essas religiões estão sujeitas e sofrem, advém do Estado através de suas instituições e agentes, deflagrando sua estrutura racista, seja pela ação ou omissão.

Este Mapa da Intolerância Religiosa nasce do desejo de várias pessoas e organizações que ao longo da última década empreenderam ações no país inteiro de combate ao desrespeito religioso que é flagrantemente cometido por indivíduos, instituições e pelos próprios órgãos do Estado, inclusive aqueles que teriam como papel fundamental proteger o direito de culto no país: o aparato de segurança pública, o Legislativo, o Executivo e o Judiciário. (GUALBERTO, 2011, p. 8)

\section{Ataques aos terreiros}

A prática de ataques e destruição de terreiros, seja pelo Estado, através de batidas policiais ou de mandatos de desapropriação20, ou ainda como ataques de cunho discriminador, sejam por denominações religiosas ou não, tem sido frequentemente relatados pelos meios midiáticos nos últimos anos.

Desde que o Ministério dos Direitos Humanos da Presidência da República instituiu o disque 100 como um canal de denuncia de violação de direitos humanos os números de denúncias de casos de discriminação religiosa tiveram um aumento

\footnotetext{
${ }^{20}$ Como no caso acima referido da Mãe de Santo Rosalice do Amor Divino que teve seu terreiro parcialmente por agentes estatais sem que tenho sido notificada da ação, em Salvador, Bahia.
} 
assustador $^{21}$. E no Estado do Rio de Janeiro, no ano de 2017, foram registrados um caso de intolerância por semana ${ }^{22}$.

No ano de 2015 ocorreram uma série de ataques a terreiros no Distrito Federal e entorno que foram noticiados pela mídia, assim como um ataque ocorrido em março de 2016, que alardeou toda a comunidade de terreiro e gerou uma movimentação política das mesmas de forma a cobrar das autoridades a solução e posicionamento do Estado frente aos ataques.

Foi um momento que desencadeou a elaboração e convocação da comunidade de terreiro para discussão sobre o cenário de violação e discriminação que sofrem, como a promoção de audiências públicas e o lançamento de frentes parlamentares para o enfrentamento da discriminação religiosa.

No Distrito Federal e entorno, entre agosto e dezembro de 2015, foram registrados mais de cinco ataques à terreiros de candomblée ${ }^{23}$. No dia 5 de agosto, o terreiro Axé Queiroz Ilê Orinlá Funfun, em Santo Antônio do Descoberto - Goiás, sofreu um primeiro ataque quando foi violado e parte de suas representações do seu sagrado $^{24}$ foram destruídas e alguns objetos roubados, como geladeira e fogão. Posteriormente houve mais dois ataques ao mesmo terreiro. No mês de setembro houve uma tentativa de incêndio ao Ilê Axé Omi Gbato Jegede, em Águas Lindas, que foi concomitante ao segundo ataque ao terreiro em Santo Antônio do Descoberto e o ataque ao Ilê axé Onibô Aráiko, em Valparaiso. Em outubro o ataque foi à casa de pai Adauto Alves da Silva, também em Valparaíso. O último ataque registrado pela mídia em tal ano resultou na queima total do Ilê Axé Oyá Bagan, no dia 27 de novembro de 2015, no Paranoá, que teve o laudo da perícia questionado pela comunidade de terreiro ${ }^{25}$.

O reflexo de tantos ataques a terreiros de candomblé levou ao anúncio do atual governador do Distrito Federal, Rodrigo Rollemberg (Partido Socialista Brasileiro PSB/DF), da criação de uma delegacia que tem como intuito o registro e apuração de

\footnotetext{
${ }^{21}$ Dados estatísticos disponíveis em: http://www.mdh.gov.br/disque100/balanco-2017-1

${ }^{22}$ Informação disponível em: https://www.menorahnet.com.br/11390-2/

${ }^{23}$ É importante frisar que existem muitos casos que não são midiatizados ou se quer denunciados o que faz com que o número de ataques possa ser ainda maior. A Fundação Palmares tem o registro de que foram 27 casos de violações de terreiros no ano de 2015.

${ }^{24}$ Foi assim que o Babalorixá responsável pelo tereiro Axé Queiroz Ilê Orinlá Funfun caracterizou a destruição de seu terreiro.

${ }^{25} \mathrm{O}$ laudo da perícia apontou que a causa do incêndio teria sido um curto circuito na fiação do terreiro. Este laudo foi questionado pelos adeptos que acreditam que essa seria uma forma de encobertar a intolerância religiosa.
} 
crimes de racismo e intolerância ${ }^{26}$. $\mathrm{O}$ anúncio foi simbólico, até por ter sido feito ao lado da mãe de santo do Ilê Axé Oyá Bagan, sobre as cinzas do terreiro queimado.

No ano de 2017 quatro terreiros de umbanda foram atacados dentro do período de uma semana, em Teresina, capital do estado do Piauí. ${ }^{27}$

O enorme número de casos de discriminação no Estado do Rio de Janeiro nos anos de 2017 e 2018, com o requinte de crueldade demonstrado através de um vídeo que circulou nas redes sociais em que a Mãe de Santo Carmem de Oxum se vê obrigada a destruir seu terreiro para que não fosse morta por um homem que a ameaçava ${ }^{28}$, também fez com que o então governador do Rio de Janeiro, Luiz Fernando Pezão, anunciasse a criação de uma Delegacia de Combate a Crimes Raciais e Delitos de Intolerância (Decradi), em agosto de $2017^{29}$, e sancionou, em 16 de janeiro de 2018, uma lei que obriga as delegacias a classificarem como crime de intolerância religiosa os casos de agressão e ofensa a adeptos e templos de qualquer denominação religiosa ${ }^{30}$.

Os casos acima relatados cumprem o papel de exemplificar os caos de ataques a terreiros, mas não tem o intuito de esgotá-los, pois mesmo nos estados citados como em outras regiões do Brasil houveram demais casos de discriminação e violação a terreiros.

Atentando para a denominação das delegacias instituídas no estado do Rio de Janeiro e no Distrito Federal, que inclui o combate a crimes raciais já pode ser considerado como um reconhecimento institucional, em algum nível, de que há uma associação entre a intolerância sofrida por afrorreligiosos e o racismo.

Contudo, é curiosa a sanção de uma lei que visa a obrigatoriedade da classificação de crimes contra adeptos e templos de denominações religiosas, pois tal lei e classificação já existem. O que fica demonstrado é o racismo institucional com a não aplicação da mesma e a necessidade de sanção de uma nova lei para que possa haver efetividade.

A lei Caó engloba os crimes resultantes de discriminação ou preconceito relacionados à religião. Nesse sentido, é possível associar, como feito anteriormente, a

\footnotetext{
${ }^{26}$ Trata-se da Delegacia de Repressão aos Crimes de Discriminação, criada em 21 de janeiro de 2016

${ }^{27}$ Informação disponível em: http://www.gp1.com.br/noticias/policia-investiga-ataques-em-terreiros-deumbanda-em-teresina-417347.html

28 Informação disponível em: https://www.nexojornal.com.br/expresso/2017/10/11/Como-aintoler\%C3\%A2ncia-religiosa-tem-se-manifestado-no-Brasil

${ }^{29}$ Informação disponível em: http://agenciabrasil.ebc.com.br/direitos-humanos/noticia/2017-08/rio-teradelegacia-especializada-para-combater-crimes-raciais-e

${ }^{30}$ Informação disponível em: https://pleno.news/brasil/cidades/policia-registrara-como-crime-casos-deintolerancia-religiosa.html
} 
Revista Calundu - vol. 2, n.1, jan-jun 2018

dificuldade de se reconhecer o racismo nesse caso expresso pelo termo intolerância e que se encontra como uma tipificação da lei.

Ao tratar de crimes ligados à discriminação de raça, etnia, credo e procedência nacional, o que se vê é que a maioria dos casos são relacionados como injúria ou ofensa, não havendo, por parte do aparato de segurança pública e do judiciário um real conhecimento - ou vontade - ao que se refere à aplicação e ao alcance desta lei. (GUALBERTO, 2011, p. 27)

Gualberto salienta ainda que até o ano de 2008 a Lei Caó não constava no sistema de delegacias legais no estado do Rio de Janeiro e acrescenta que após a inclusão no sistema os registros passaram a ser quase diários. (2011, p. 26-27).

Essa dificuldade em se nomear o racismo deriva-se da forma com que o racismo foi construído no Brasil. A classificação não é feita porque não se quer assumir o racismo presente na sociedade assim como na estruturação de todas as instituições estatais. Fato que acaba por fortalecer a invisibilização do racismo em sua vertente religiosa.

Para além de demonstrar uma espécie de racismo institucional que demonstra quão distante as instituições estão da sociedade, mostrando assim uma das faces de sua exterioridade; também comprova a distância entre as comunidades de terreiro e o Estado, isso porque, como evidencia Segato (2007) o estado não é um aliado das comunidades de terreiro. Pelo contrário, é um de seus maiores violadores. O Estado age assim, como um perpetrador do racismo religioso mediado pelo racismo institucional.

\section{Considerações finais}

O histórico de violações e discriminações as religiões afro-brasileiras exemplificado a partir de alguns casos em suas variadas instâncias tem como embasamento o racismo. Essa afirmação pode ser evidenciada com a condenação, criminalização, perseguição e proibição das práticas, valores, saberes, conhecimentos e compreensões de mundo que destoem da construção hegemônica preconizada pelo ideal civilizacional ocidental.

Concordo com Flor do Nascimento (2017) quando afirma que o que está em jogo e presente nas várias atuações da intolerância religiosa é o fato de que as origens africanas e indígenas das religiões afro-brasileira que, mais que religiões, são expressões de uma forma de vida complexa e 'outra' que se difere a partir de sua 
Revista Calundu - vol. 2, n.1, jan-jun 2018

compreensão de mundo, valores, saberes do que é proposto como "norte" civilizacional europeu ocidental. E, exatamente por ser outra forma, é que as comunidades de terreiros devem ser reconhecidas como comunidades de resistência ao racismo. (p. 54)

\section{Referências Bibliográficas}

BLANCARTE, Roberto J. Discriminación por motivos religiosos y Estado laico: elementos para uma discusión. Estudios Sociológicos, v. XXI, n. 2, pp.279- 307, 2003.

Laicidad y laicismo en América latina. Notas críticas de Estudios Sociológicos, v. XXVI, n. 76, pp. 139-164, 2008.

BRASIL. Constituição da República Federativa do Brasil. Brasília, DF: Senado Federal, 1988. Disponível em:

http://www.senado.gov.br/legislacao/const/con1988/CON1988_05.10.1988/CON1988.p df Acesso em: 10 mai. 2015.

Um panorama da diversidade religiosa. Secretaria de Direitos Humanos da Presidência da República. Disponível em http://www.sdh.gov.br/assuntos/direito-paratodos/programas/diversidade-religiosa Acesso em: 10 mai. 2015.

Decreto-Lei 2.848, de 07 de dezembro de 1940. In: Diário Oficial da União.

Rio de Janeiro: DOU, 1940. Disponível em:

http://www2.camara.leg.br/legin/fed/declei/1940-1949/decreto-lei-2848-7-dezembro1940-412868-publicacaooriginal-1-pe.html

Lei no 7.716 de 05 de janeiro de 1989. In: Diário Oficial da União. Brasília: DOU, 1989.

Código Criminal, 1830. Disponível em:

http://www.planalto.gov.br/ccivil_03/leis/lim/LIM-16-12-1830.htm

Decreto 2.710 de 04 de agosto de 1998. In: Diário Oficial do Distrito Federal. Brasília: DOU, 1998.

CAPUTO, Stella. G. Educação nos terreiros - e como a escola se relaciona com as crianças do candomblé. Rio de Janeiro: Ed. Pallas, 2012. 296p 
CARBONARI, Paulo C. Sujeito de direitos humanos: questões abertas e em construção. In: SILVEIRA, Rosa M. et al. Educação em direitos humanos: fundamentos teóricometodológicos. João Pessoa: Universitária, 2007.

CASANOVA, José. Public religions in the modern world. Chicago: The University of Chicago Press, 1994.

CAVALIERE, Ana M. O mal-estar do ensino religioso nas escolas públicas. Cadernos de Pesquisa, v. 37, p. 303-332, 2007.

DINIZ, Débora; LIONÇO, Tatiana; CARRIÃO, Vanessa. Laicidade e ensino religioso no Brasil. Brasília: UNESCO: Letras Livres: Ed. UnB, 2010. 112p

DUSSEL, Enrique. 1994. 1492: el encubrimiento del otro : hacia el origen del mito de la modernidad: La Paz: Plural editores: UMSA,1994. Disponível em: < http://bibliotecavirtual.clacso.org.ar/clacso/otros/20111218114130/1942.pdf >

FERNANDES, Nathália V. E. A raiz do pensamento colonial na intolerância religiosa contra religiões de matriz africana. Revista Calundu - vol. 1, n.1, jan-jun 2017.

FLOR do NASCIMENTO, Wanderson Flor. Intolerância ou racismo? Jornal Hora Grande, Outubro - Ano XXI - Edição 167. 2016

O Fenômeno do Racismo Religioso: Desafios para os Povos Tradicionais de Matriz Africana. Brasília-DF, v. 6, n. 2 (Especial), novembro de 2017

FRIAS, Eduardo R.; RIBEIRO, Ronilda. A professora destruiu minha pulseira de orixá e todo mundo riu: o psicólogo escolar diante da discriminação religiosa. In: Psicologia, Laicidade e as relações com a religião e a espiritualidade. Laicidade, Religião, Direitos Humanos e Políticas Públicas - Volume 1. São Paulo, 2016.

GIUMBELLI, Emerson. A presença do religioso no espaço público: modalidades no Brasil. Religião e Sociedade, v. 28, n. 2: Rio de Janeiro. 2008 
GUALBERTO, Márcio Alexandre M. Mapa da Intolerância Religiosa: violação ao direito de culto no Brasil - 2011. Ed. Multiplike.

MAGGIE, Yvonne. Medo de feitiço: relações entre magia e poder no Brasil. Rio de Janeiro. Arquivo Nacional. 1992.

OLIVEIRA, Ariadne Moreira Basílio. Modernidade, raça e intolerância: direitos humanos na encruzilhada. Em: Anais Encontro da ANDHEP- Direitos humanos, sustentabilidade, circulação global e povos indígenas. Vitória (ES). 2016

- Religiões afro-brasileiras e o Racismo: contribuição para a categorização do racismo religioso. Dissertação (mestrado) Programa de PósGraduação em Direitos humanos e Cidadania do Centro de Estudos Avançados Multidisciplinares da Universidade de Brasília, 2017.

OLIVEIRA, Luiz Fernandes de; RODRIGUES, Marcelino Euzébio. A cruz, o ogó e o oxê: religiosidades e racismo epistêmico na educação carioca. In: REUNIÃO ANUAL DA ASSOCIAÇÃO NACIONAL DE PESQUISADORES EM EDUCAÇÃO, 36., 2013, Goiânia. Anais. Goiânia: Anped, 2013.

PAES, Mariana D. O tratamento jurídico dos escravos nas Ordenações Manuelinas e Filipinas. Comunicação apresentada no V Congresso Brasileiro de História do Direito (Curitiba). 2011

PACHECO. Lwdimila C. Racismo e Intolerância Religiosa: Representações do Xangô nos jornais de Maceió entre 1905 e 1940. Sankofa. Revista de História da África e de Estudos da Diáspora Africana Ano VIII, NXV, Agosto, pp. 80-109, 2015.

PAULY, Evaldo Luís. O dilema epistemológico do ensino religioso. Revista Brasileira de Educação, n. 27, p. 172-182, 2004. 
PETEAN. Antônio Carlos L. O racismo como questão epistemológica: uma interpretação do discurso religioso evolucionista da Igreja Universal do Reino de Deus. Tese (Doutorado) programa de pós-graduação em Sociologia da Faculdade de Ciênciase Letras da Universidade Estadual Paulista. 2011

QUIJANO, Aníbal. La modernidade, el capital y América Latina nascen el mismo día. ILLA - Revista del Centro de Educación y Cultura, n.10, Lima, janeiro, pp. 42-57, 1991.

Colonialidad y modernidad-racionalidad. In: Aníbal Quijano. Textos de fundación. Buenos Aires: Ediciones del Signo, 2014.

QUINTANA, Eduardo. INTOLERÂNCIA RELIGIOSA NA ESCOLA: O que professoras filhas de santo tem a dizer sobre esta forma de violência. Revista Forum Identidades. GEPIADDE, Ano 07, Volume 14 | jul./dez. de 2013.

RAFAEL, Ulisses Neves. Xangô rezado baixo: um estudo da perseguição aos terreiros de Alagoas em 1912. 2004. 266 f. Tese (Doutorado em Sociologia e Antropologia) UFRJ - IFCS: Programa de Pós Graduação em Sociologia e Antropologia, Rio de Janeiro. 2004.

REINHARDT, Bruno M. N. Espelho ante espelho: a troca e a guerra entre o neopentecostalismo e os cultos afro-brasileiros em Salvador. Dissertação (Mestrado) Programa de Pós Graduação em Antropologia Social da Universidade de Brasília, 2006.

RUSSO, Kelly e ALMEIDA, Alessandra. Yalorixás e educação: discutindo o ensino religioso nas escolas. Cadernos de Pesquisa v.46 n.160 p.466-483 abr./jun. 2016477

SANTOS, Edmar Ferreira. O poder dos candomblés: perseguição e resistência no Recôncavo da Bahia. Salvador: EDUFBA, 2009. 209 p. 
SANTOS, Ivair. Direitos Humanos e as Práticas de Racismo. Direitos Humanos e as Práticas de racismo: o que faremos com os brancos racistas. 2009. 514f. Tese (Doutorado em Sociologia) - Departamento de Sociologia, Universidade de Brasília, Brasília. 2009

SEGATO, Rita L. Ciudadania: Por que no? Estado y sociedad en el Brasil a la luz de un discurso religioso afro-brasileño. In: La nación y sus otros. Raza, etnicidad y diversidade religiosa en tiempos de Políticas de la Identidad. Buenos Aires: Prometeo Libros, 2007.

SILVA, Vagner Gonçalves da. Prefácio ou Notícias de uma Guerra Nada Particular: Os Ataques Neopentecostais às Religiões Afro-brasileiras e aos Símbolos da Herança Africana no Brasil. In: Intolerância religiosa. Impactos do neopentecostalismo no campo religioso afro-brasileiro. São Paulo, EDUSP, 2007.

Recebido em: 15/05/208

Aceito em: 30/05/2018 